\title{
ASPEK REDUPLIKASI DALAM NOVEL RARA MENDUT KARYA Y.B. MANGUNWIJAYA
}

\author{
Ila Nafilah ${ }^{1}$, Yulia Agustin ${ }^{2}$, Dorra Farhana ${ }^{3}$ \\ Program Studi Pendidikan Bahasa dan Sastra Indonesia, \\ Fakultas Bahasa dan Seni, Universitas Indraprasta PGRI \\ ${ }^{1}$ nafilah.salsabila@gmail.com, ${ }^{2} y u l i a a g u s t i n . u n i n d r a @ g m a i l . c o m,{ }^{3}$ dorrafarhana21@gmail.com
}

\begin{abstract}
Abstrak
Objek morfologi adalah hal-hal yang berhubungan dengan bentuk kata atau struktur kata dalam bahasa. Dalam kajian morfologi, terdapat adanya jenis-jenis proses morfologis, salah satunya berkaitan dengan proses reduplikasi (bentuk ulang). Kata ulang atau reduplikasi adalah proses pengulangan satuan gramatik, baik seluruhnya atau sebagian, baik dengan variasi fonem maupun tidak. Reduplikasi atau perulangan adalah proses pengulangan kata atau unsur kata. Reduplikasi juga merupakan proses penurunan kata dengan perulangan utuh maupun sebagian. Pendekatan penelitian yang digunakan dalam penelitian ini adalah pendekatan penelitian kualitatif. Pendekatan penelitian kualitatif tidak menggunakan perhitungan, maksudnya data yang akan dianalisis tidak berbentuk angka-angka. Berkaitan dengan hal itu, maka sumber data dalam penelitian ini adalah data yang berupa dokumen, yakni novel Rara Mendut Karya Y.B. Mangunwijaya. Data dalam penelitian ini adalah kutipan-kutipan berupa kata, frasa, kalimat, atau wacana yang berkaitan dengan aspek reduplikasi seperti reduplikasi utuh atau murni, reduplikasi berubah bunyi, reduplikasi sebagian, dan reduplikasi berimbuhan. Tujuan dilaksanakannya penelitian ini adalah untuk menganalisis dan memperoleh gambaran yang jelas mengenai aspek reduplikasi, seperti reduplikasi utuh atau murni, reduplikasi berubah bunyi, reduplikasi sebagian, dan reduplikasi berimbuhan dalam novel Rara Mendut karya Y.B. Mangunwijaya.
\end{abstract}

Kata Kunci: morfologi, reduplikasi, dan aspek reduplikasi.

\begin{abstract}
Morphological objects are things that relate to word forms or word structures in language. In the study of morphology, there are types of morphological processes, one of which is related to the process of reduplication (re-form). Re-word or reduplication is the process of repeating grammatical units, either in whole or in part, whether or not with phoneme variations. Reduplication is the process of repeating words or elements of words. Reduplication is also a process of decreasing words with whole or partial repetition. The research approach used in this study is a qualitative research approach. The qualitative research approach does not use calculations, meaning that the data to be analyzed is not in the form of numbers. Related to this, the source of data in this study is data in the form of documents, namely novel Rara Mendut Karya Y.B. Mangunwijaya. The data in this study are excerpts in the form of words, phrases, sentences, or discourse relating to aspects of reduplication such as full or pure reduplication, reduplication change in sound, partial reduplication, and reduplication with impact. The purpose of this research is: to analyze and obtain a clear picture of the aspects of reduplication, such as complete or pure reduplication, reduplication change in sound, partial reduplication, and reduplication affected in the novel Rara Mendut by Y.B. Mangunwijaya.
\end{abstract}

Keywords: morphology, reduplication, and reduplication aspects. 


\section{PENDAHULUAN}

Ilmu linguistik terdiri dari beberapa bidang keilmuan di antaranya fonologi, morfologi, sintaksis, semantik dan wacana. Hal ini sebagaimana diungkapkan oleh Chaer (2007:3) yang menyatakan bahwa ilmu linguistik disebut juga linguistik umum (general liguistics) yang tidak hanya mengkaji sebuah bahasa saja, seperti bahasa Jawa atau bahasa Arab, melainkan mengkaji seluk beluk bahasa pada umumnya. Kridalaksana (dalam Rohmadi, dkk., 2010:3) menyatakan bahwa hakikat morfologi adalah bidang linguistik yang mempelajari morfem dan kombinasi-kombinasinya. Objek morfologi adalah hal-hal yang berhubungan dengan bentuk kata atau struktur kata dalam bahasa. Dalam kajian morfologi, terdapat adanya jenis-jenis proses morfologis, salah satunya berkaitan dengan proses reduplikasi (bentuk ulang). Reduplikasi ialah proses morfologis melalui peristiwa pengulangan bentuk yang menghasilkan bentuk ulang (Rohmadi, dkk., 2010:49).

Kata ulang atau reduplikasi adalah proses pengulangan satuan gramatik, baik seluruhnya atau sebagian, baik dengan variasi fonem maupun tidak. Hasil pengulangan itu disebut kata ulang, sedangkan satuan yang diulang merupakan bentuk dasarnya (Ramlan, 2001:64). Reduplikasi atau bentuk pengulangan dalam bahasa Indonesia yang terjadi pada tataran fonologis, morfologis, maupun tataran sintaksis. Reduplikasi atau perulangan adalah proses pengulangan kata atau unsur kata. Reduplikasi juga merupakan proses penurunan kata dengan perulangan utuh maupun sebagian. Dalam bahasa Indonesia reduplikasi merupakan mekanisme atau aturan yang penting dalam pembentukan kata.

Reduplikasi merupakan salah satu unsur kebahasaan yang sering digunakan dalam percakapan sehari-hari, maupun dalam karya sastra. Berbagai bentuk karya sastra, salah satu di antaranya adalah novel. Novel merupakan salah satu genre sastra di samping cerita pendek, puisi, dan drama. Novel adalah cerita atau rekaan (fiction), disebut juga teks naratif (narrative text) atau wacana naratif (narrative discourse) (Al-Ma'ruf, 2006:17). Bahasa dan sastra memang sangat erat kaitannya, sebab bahasa merupakan media untuk penyampaian sebuah karya sastra. Begitu juga dengan novel Rara Mendut Karya Y.B. Mangunwijaya yang banyak terdapat reduplikasi atau pengulangan kata. Hal ini dikarenakan agar mempermudah pembaca dalam memahami isi bacaan novel tersebut.

Peneliti tertarik menggunakan novel Rara Mendut sebab Y.B. Mangunwijaya yang mempunyai nama lengkap Yusuf Bilyarta Mangunwijaya dan nama samarannya Wastuwijaya atau Thalib Yusuf. Seorang pastor yang lebih dikenal dengan panggilan Romo Mangun ini lahir 6 Mei 1929 di Ambarawa, Jawa Tengah, dan meninggal 10 Februari 1999 tidak hanya dikenal sebagai sastrawan, tetapi juga dikenal sebagai rohaniwan, budayawan, arsitek, penulis, aktivis dan pembela wong cilik. Pada 1972 ia mulai menuangkan pengalamannya dalam artikel, esai, dan cerpen yang dimuat di media massa.

Salah satu cerpen yang terhimpun dalam Dari Jodoh Sampai Supiyah memperoleh Hadiah Kincir Emas dari Radio Nederland. Novel pertama berjudul Romo Rahardi, novel psikologi diterbitkan tahun 1981 oleh Dunia Pustaka Jaya. Burung-Burung Manyar, novel revolusi Indonesia, diterbitkan oleh Djambatan tahun 1981. Novel ini memenangi South East Asia Write Award tahun 1983 dari Kerajaan Thailand dan telah diterjemahkan ke dalam bahasa Belanda, Jepang, dan Inggris. Novel Ikan-Ikan Hiu, Ido, Homa, novel sejarah Halmahera Maluku Abad Ke-17, diterbitkan oleh Sinar Harapan tahun 1983 dan cetakan kedua diterbitkan oleh Djambatan tahun 1987. Trilogi novel Roro Mendut, Genduk Duku, dan Lusi Lindri, merupakan novel akhir zaman Sultan Agung dan 
Susuhunan Mangkurat I abad 17, diterbitkan tahun 1983-1986 oleh Gramedia. Balada Becak, Fantasi, Humor, diterbitkan tahun 1985 oleh Balai Pustaka.

Penelitian ini difokuskan pada analisis aspek reduplikasi dalam novel Rara Mendut Karya Y.B. Mangunwijaya. Novel yang diangkat dan dikembangkan dari kisah rakyat Babad Tanah Jawi dan berbagai sumber oleh Y.B. Mangunwijaya ini terdiri dari tiga buku atau merupakan sebuah novel trilogi. Buku pertama mengisahkan tentang Rara Mendut yang terdiri dari 26 bab, buku kedua mengisahkan tentang Genduk Duku yang terdiri dari 25 bab, dan buku ketiga mengisahkan tentang Lusi Lindri yang terdiri dari 27 bab.

Rumusan masalah dalam penelitian ini adalah: Bagaimanakah aspek reduplikasi dalam novel Rara Mendut karya Y.B. Mangunwijaya? Tujuan dilaksanakannya penelitian ini adalah untuk menganalisis dan memperoleh gambaran yang jelas mengenai aspek reduplikasi, seperti reduplikasi utuh atau murni, reduplikasi berubah bunyi, reduplikasi sebagian, dan reduplikasi berimbuhan dalam novel Rara Mendut karya Y.B. Mangunwijaya.

Di dalam suatu penelitian untuk memperdalam pemahaman tentang masalah yang akan diteliti, maka diperlukan tinjauan pustaka. Berikut merupakan beberapa tinjauan pustaka yang digunakan dalam penelitian ini.

\section{Hakikat Morfologi}

Chaer (2015: 3) menyatakan bahwa secara etimologi kata morfologi berasal dari kata morf yang berarti 'bentuk' dan kata logi yang berarti 'ilmu'. Jadi, secara harfiah kata morfologi berarti 'ilmu mengenai bentuk'. Di dalam kajian linguistik, morfologi berarti 'ilmu mengenai bentuk-bentuk dan pembentukan kata', sedangkan di dalam kajian biologi morfologi berarti 'ilmu mengenai bentuk-bentuk sel-sel tumbuhan atau jasadjasad hidup'. Morfologi menurut Alwi (2003: 35) adalah "subdisiplin" linguistik yang menelaah bentuk, proses dan pembentukan kata. Menurut Verhaar (2004: 11) ilmu morfologi menyangkut struktur "internal" kata. Seperti kata tertidur kata ini terdiri atas dua morfem yakni -ter dan tidur. (ter- diberi garis karena tidak pernah berdiri sendiri). Berbagai pendapat para ahli tentang morfologi dapat ditarik kesimpulan bahwa morfologi adalah ilmu yang mempelajari bentuk kata.

\section{Hakikat Reduplikasi}

Menurut Rohmadi, dkk. (2012:83) menyebutkan bahwa reduplikasi merupakan perulangan bentuk atas bentuk dasar. Contohnya seperti buku-buku (bentuk dasarnya buku), tanaman-tanaman (bentuk dasarnya tanaman), dan sebagainya. Rohmadi, dkk. (2012:86) juga mengelompokkan kata ulang berdasarkan cara pengulangannya menjadi enam golongan yakni perulangan seluruh bentuk dasar tanpa variasi fonem dan afiksasi, perulangan sebagian (meliputi pengulangan sebagian dengan kata dasar bentuk tunggal dan perulangan sebagian dengan kata dasar bentuk kompleks), perulangan dengan berimbuhan atau afiksasi, perulangan dengan variasi fonem/dengan perubahan bunyi, kata ulang semu, dan kata ulang bentuk unik. Chaer (2003:182) juga mengemukakan bahwa reduplikasi adalah proses morfemis yang mengulang bentuk dasar, baik secara keseluruhan, secara sebagian (parsial) maupun dengan perubahan bunyi.

Reduplikasi ialah proses pembentukan kata yang mengubah leksem atau bentuk dasar menjadi kata kompleks dengan beberapa macam pengulangan, yakni pengulangan seluruh, sebagian, berimbuhan, dan berubah bunyi (Ridwan, 2018). Bentuk reduplikasi merupakan salah satu proses morfologi yang mempunyai hubungan antara bentuk dasar dan bentuk asal (Due, 2016). 


\section{Jenis-jenis Reduplikasi}

Dilihat dari hasil pengulangannya, reduplikasi dapat dibedakan empat macam, yaitu (1) reduplikasi utuh atau murni, (2) reduplikasi berubah bunyi, (3) reduplikasi sebagian, dan

(4) reduplikasi berimbuhan (Chaer, 2006:286), seperti:

1. Kata ulang murni adalah kata ulang yang bagian perulangannya sama dengan kata dasar yang diulanginya.

Contoh: rumah-rumah $\rightarrow$ (bentuk dasar: rumah), makan-makan $\rightarrow$ (bentuk dasar: makan)

2. Kata ulang berubah bunyi adalah kata ulang yang bagian perulangannya terdapat perubahan bunyi, baik bunyi vokal maupun konsonan.

Contoh: Perubahan vokal: bolak-balik, larak-lirik, Perubahan konsonan: sayur-mayur, ramah-tamah

3. Kata ulang sebagian, yaitu kata ulang yang perulanganya hanya terjadi pada suku kata awalnya saja dan disertai dengan penggantian vokal suku pertama itu dengan bunyi é pepet.

Contoh: leluhur $\rightarrow$ bentuk dasar: luhur, lelaki $\rightarrow$ bentuk dasar: laki

4. Kata ulang berimbuhan, yaitu kata ulang yang disertai dengan pemberian imbuhan. Menurut proses pembentukannya ada tiga macam kata ulang berimbuhan, yaitu:

a. Sebuah kata dasar mula-mula diberi imbuhan, kemudian baru diulang. Umpamanya pada kata dasar atur, mula-mula diberi akhiran -an sehingga menjadi aturan. Kemudian kata aturan ini diulang sehingga menjdai aturan-aturan.

Contoh lain: bangunan-bangunan, kegiatan-kegiatan

b. Sebuah kata dasar mula-mula diulang, kemudian baru diberi imbuhan. Umpamanya kata lari mula-mula diulang sehingga menjadi lari-lari. Kemudian kata lari-lari diberi awalan ber- sehingga menjadi berlari-lari.

Contoh lain: melihat-lihat, melompat-lompat

c. Sebuah kata dasar diulang dan sekaligus diberi imbuhan. Umpamanya pada kata dasar hari sekaligus diulang dan diberi awalan ber- sehingga menjadi bentuk berhari-hari.

Contoh lain: berton-ton, bermil-mil.

\section{METODE PENELITIAN}

Pendekatan penelitian yang digunakan dalam penelitian ini adalah pendekatan penelitian kualitatif. Pendekatan penelitian kualitatif tidak menggunakan perhitungan, maksudnya data yang akan dianalisis tidak berbentuk angka-angka. Hal ini sesuai dengan pendapat Moleong (2011: 11) yang mengatakan bahwa data yang dikumpulkan berupa kata-kata, gambar, dan bukan angka-angka. Menurut Lofland dan Lofland (dalam Moleong, 2007: 157) sumber data utama dalam penelitian kualitatif ialah kata-kata dan tindakan, selebihnya adalah data tambahan seperti dokumen dan lain-lain.

Berkaitan dengan hal itu, maka sumber data dalam penelitian ini adalah data yang berupa dokumen, yakni novel Rara Mendut Karya Y.B. Mangunwijaya. Data dalam penelitian ini adalah kutipan-kutipan berupa kata, frasa, kalimat, atau wacana yang berkaitan dengan aspek reduplikasi seperti reduplikasi utuh atau murni, reduplikasi berubah bunyi, reduplikasi sebagian, dan reduplikasi berimbuhan.

\section{Fokus dan Subfokus Penelitian}

Sehubungan dengan tujuan khusus penelitian, maka penelitian ini memfokuskan pada novel Rara Mendut karya Y.B. Mangunwijaya. Subfokus dalam penelitian ini yaitu aspek 
reduplikasi yang terdiri dari reduplikasi utuh atau murni, reduplikasi berubah bunyi, reduplikasi sebagian, dan reduplikasi berimbuhan.

\section{HASIL DAN PEMBAHASAN}

\section{Deskripsi Informasi Penelitian}

Deskripsi informasi penelitian adalah gambaran mengenai data yang diteliti. Data aspek reduplikasi yang diteliti bersumber dari novel Rara Mendut karya Y.B. Mangunwijaya. Aspek-aspek reduplikasi yang terdapat dalam novel akan diteliti berdasarkan reduplikasi utuh atau murni, reduplikasi berubah bunyi, reduplikasi sebagian, dan reduplikasi berimbuhan.

\section{Analisis Data}

\section{Aspek Reduplikasi Sebagian}

1. Pada bab $1 \mathrm{hlm}$. 4, terdapat kalimat yaitu "Tetap biarlah, pada saatnya sendiri dia toh akan belajar bergaul biasa dengan para putri duyung yang sering muncul di kalangan kaum kecil, yakni perempuan-perempuan muda dini yang berjiwa jantan, gesit, cerdas, dan yang harus diakui, dalam banyak hal menang terhadap kaum lelaki." Dari kalimat tersebut terdapat aspek reduplikasi sebagian pada kata lelaki yang merupakan bentuk lain dari aspek reduplikasi utuh laki-laki yang bermakna golongan jenis kelamin pria.

2. Pada bab 2 hlm. 22, terdapat kalimat yaitu "Banyak gadis di dalam peperangan diperkosa, kata ibuku, Nduk, tetapi bila itu melawan kemauan, mereka masih perawan". Dari kalimat tersebut terdapat dua aspek reduplikasi sebagian, yaitu pada kata peperangan yang merupakan bentuk lain dari aspek reduplikasi utuh perang yang bermakna permusuhan antara dua negara (bangsa, agama, suku, dan sebagainya); pertempuran besar bersenjata antara dua pasukan atau lebih (tentara, laskar, pemberontak, dan sebagainya); perkelahian; konflik, sedangkan peperangan sendiri bermakna hal berperang Selain itu, juga terdapat kata tetapi yang merupakan bentuk lain dari aspek reduplikasi utuh tapi. kata tetapi bermakna kata penghubung intrakalimat untuk menyatakan hal yang bertentangan atau tidak selaras.

3. Pada bab 3 hlm. 25, terdapat kalimat yaitu "Maka mulailah perjalanan yang masih jauh melalui sawah, padang, desa-dukuh, dan hutan rimba, sebelum sampai di istana yang baru, di sana di balik pegunungan Kendheng dan gunung-gunung raksasa Merbabu dan Merapi.”. Dari kalimat tersebut terdapat aspek reduplikasi sebagian, yaitu pada kata pegunungan yang merupakan bentuk lain dari aspek reduplikasi utuh gunung yang bermakna bukit yang sangat besar dan tinggi (biasanya tingginya lebih dari $600 \mathrm{~m}$ ), sedangkan pegunungan sendiri bermakna tempat yang bergununggunung (terdiri atas gunung-gunung).

4. Pada bab 14 hlm. 158, terdapat kalimat yaitu "Dasar lelaki suka ditipu!" Dari kalimat tersebut terdapat aspek reduplikasi sebagian pada kata lelaki yang merupakan bentuk lain dari aspek reduplikasi utuh laki-laki yang bermakna golongan jenis kelamin pria.

\section{Aspek Reduplikasi Berubah Bunyi}

1. Pada bab $5 \mathrm{hlm}$. 50, terdapat kalimat yaitu "Dan bila ada yang bermurah hati, kemudian mesiu dimasukkan dari depan laras lalu dinyalakan dengan bunyi letusan yang menambah hiruk-pikuk di sekelilingnya maka tertawa berjingkrak-jingkrak anak-anak itu sangat girang sambil mebual kepada teman-temannya." Dari kalimat tersebut terdapat aspek reduplikasi berubah bunyi pada kata hiruk-pikuk yang bermakna ramai. 
2. Pada bab $6 \mathrm{hlm} .59$, terdapat kalimat yaitu “... balatentara Mataram dengan soraksorai dahsyat dan terhela oleh bendhe-bendhe perang yang dipimpin oleh bendhe termashyur Kiai Bicak, membanjir ke dalam kota Madiun, mengobrak-abrik tentara lawan yang pontang-panting lari karena ...". Dari kalimat tersebut terdapat aspek reduplikasi berubah bunyi pada kata sorak-sorai yang bermakna suara teriak dan pekik beramai-ramai dan pada kata pontang-panting yang bermakna berlari lintang pukang, dan pada kata mengobrak-abrik yang bermakna membuat berantakan.

3. Pada bab $7 \mathrm{hlm}$. 80, terdapat kalimat yaitu "Sesudah berwawan-cakap basa-basi secukupnya, bertanyalah Wiraguna, "Kau tidak lelah, Adinda Ajeng?" Dari kalimat tersebut terdapat aspek reduplikasi berubah bunyi pada kata basa-basi yang bermakna adap sopan santun atau tata krama.

4. Pada bab 9 hlm. 104, terdapat kalimat yaitu "Memang Wiraguna sudah bangun sebetulnya, tetapi malas dan Cuma komat-kamit mulutnya, menguap, cungar-cungir ogah." Dari kalimat tersebut terdapat aspek reduplikasi berubah bunyi pada kata komat-kamit yang bermakna mulut yang bergerak-gerak.

5. Pada bab $10 \mathrm{hlm}$. 115, terdapat kalimat yaitu “... garis-garis gelombang pamor dalam perbandingan selisih hitam putihnya, lagi sebab-musabab mengapa sekian butir pamor justru harus berhadapan dengan lekuk-lekuk itu." Dari kalimat tersebut terdapat aspek reduplikasi berubah bunyi pada kata sebab-musabab yang bermakna berbagai sebab atau asal mula yang menjadi sebab atau menyebabkan.

6. Pada bab $11 \mathrm{hlm}$. 121, terdapat kalimat yaitu "Panglima Wiraguna jadi menghaturkan keprihatinannya kepada Sri Baginda tentang gerak-gerik para Adipati Panarukan, Pasuruhan, dan Blambangan akhir-akhir ini." Dari kalimat tersebut terdapat aspek reduplikasi berubah bunyi pada kata gerak-gerik yang bermakna berbagai gerak atau tingkah laku.

\section{Aspek Reduplikasi Berimbuhan}

1. Pada bab 3 hlm. 28, terdapat kalimat yaitu "Sungguh tidaklah mudah bagi prajuritprajurit regu itu, apalagi bagi Mendut dan kawan-kawannya untuk menguasai sarafsaraf tawa mereka; yang akhirnya meletus dalam gelak ketawa tak ketolong sampai perut-perut kaku semua." Dari kalimat tersebut terdapat aspek reduplikasi berimbuhan - nya pada kata kawan-kawannya yang bermakna teman-teman Mendut.

2. Pada bab 20 hlm. 239, terdapat kalimat yaitu "Sekaligus, sesuai yang diperintahkan Tumenggung, berikhtiar mengerti keadaan sedalam-dalamnya apa yang dirasakan rakyat kecil?" Dari kalimat tersebut terdapat aspek reduplikasi berimbuhan se-nya pada kata sedalam-dalamnya yang bermakna sedalam mungkin atau sungguhsungguh.

3. Pada bab 21 hlm. 247, terdapat kalimat yaitu “... sewaktu-waktu bila perlu, dapat menolong dengan kewibawaannya sebagai seorang istri Wiraguna." Dari kalimat tersebut terdapat aspek reduplikasi berimbuhan se-pada kata sewaktu-waktu yang bermakna tidak tentu waktunya atau kapan-kapan.

4. Pada bab $22 \mathrm{hlm}$. 251, terdapat kalimat yaitu "Sedih mengingat nasibnya, tetapi ikhlas. Berlinang-linang air mata." Dari kalimat tersebut terdapat aspek reduplikasi berimbuhan ber- pada kata berlinang-linang yang bermakna berlelehan.

5. Pada bab $23 \mathrm{hlm}$. 258, terdapat kalimat yaitu "Tombak berang meluncur, menghancurkan cermin, yang jatuh berkeping-keping dengan bunyi yang gemerincing." Dari kalimat tersebut terdapat aspek reduplikasi berimbuhan ber- pada kata berkeping-keping yang bermakna pecah menjadi kepingan kecil. 
6. Pada bab $24 \mathrm{hlm}$. 265, terdapat kalimat yaitu "Betapa kalah raungan yang terlalu dihebat-hebatkan." Dari kalimat tersebut terdapat aspek reduplikasi berimbuhan dikan pada kata dihebat-hebatkan yang bermakna dibuat terkesan hebat.

7. Pada bab $26 \mathrm{hlm} .276$, terdapat kalimat yaitu "Dengan latar belakang laut pasang yang menderu-deru, Wiraguna dan Pranacitra mengambil kedudukan." Dari kalimat tersebut terdapat aspek reduplikasi $m e N$ - pada kata menderu-deru yang bermakna menderu berulang kali.

\section{Aspek Reduplikasi Utuh atau Murni}

1. Pada bab 6 hlm. 64, terdapat kalimat yaitu "... yang lingkaran serta jeruji-jerujinya berbentuk keris serta bunga-bunga melati kesuma, dan yang berkilauan megah bersama dengan bandul kalung dari ukiran lempeng-lempeng emas berkarat tua." Dari kalimat tersebut terdapat aspek reduplikasi utuh pada kata bunga-bunga yang bermakna beberapa bunga melati dan pada kata lempeng-lempeng yang bermakna keeping emas berbentuk pipih.

2. Pada bab $10 \mathrm{hlm} .115$, terdapat kalimat yaitu “... garis-garis gelombang pamor dalam perbandingan selisih hitam putihnya, lagi sebab-musabab mengapa sekian butir pamor justru harus berhadapan dengan lekuk-lekuk itu." Dari kalimat tersebut terdapat aspek reduplikasi utuh pada kata garis-garis yang bermakna beberapa garis dan pada kata lekuk-lekuk yang bermakna rongga-rongga lekungan.

3. Pada bab 10 hlm. 118, terdapat kalimat yaitu "Apa hikmah huruf-huruf Jawa?" Dari kalimat tersebut terdapat aspek reduplikasi utuh pada kata huruf-huruf yang bermakna kumpulan huruf.

4. Pada bab $11 \mathrm{hlm}$. 121, terdapat kalimat yaitu "Panglima Wiraguna jadi menghaturkan keprihatinannya kepada Sri Baginda tentang gerak-gerik para Adipati Panarukan, Pasuruhan, dan Blambangan akhir-akhir ini." Dari kalimat tersebut terdapat aspek reduplikasi utuh pada kata akhir-akhir yang bermakna belakangan ini atau beberapa waktu kebelakang.

5. Pada bab 12 hlm. 142, terdapat kalimat yaitu "Ada sesuatu dalam pancaran wajahnya, yang mengingatkannya kepada putri-putri benua-benua jauh." Dari kalimat tersebut terdapat aspek reduplikasi utuh pada kata putri-putri yang bermakna beberapa putri dan pada kata benua-benua yang bermakna beberapa benua.

6. Pada bab $14 \mathrm{hlm}$. 158, terdapat kalimat yaitu "Naik dhingklik dan panjatan apa saja yang tinggi sambil memanjangkan leher-leher, semua di pasar ingin tahu apa yang tampak di pusat perhatian." Dari kalimat tersebut terdapat aspek reduplikasi utuh pada kata leher-leher yang bermakna bagian tubuh yang menghubungkan bagian kepala dengan tubuh.

7. Pada bab 15 hlm. 162, terdapat kalimat yaitu "Wiraguna sendiri sedang menghibur diri dengan gambar-gambar segulungan wayang-beber yang ter-jereng di hadapannya." Dari kalimat tersebut terdapat aspek reduplikasi utuh pada kata gambar-gambar yang bermakna beberapa gambar.

8. Pada bab $16 \mathrm{hlm}$. 167, terdapat kalimat yaitu "Ya begitulah, Mendut dan para dayangnya masih sederhana dalam harapan-harapan mereka, sebentar lagi dapat menghirup kemerdekaan." Dari kalimat tersebut terdapat aspek reduplikasi utuh pada kata harapan-harapan yang bermakna keingininan-keinginan supaya menjadi kenyataan.

9. Pada bab 17 hlm. 209, terdapat kalimat yaitu "Bolehlah disebut sebentuk keluh kesah tentang impian memudar mengenai menara-menara gading bermutiara dan bata- 
bata intan berlian yang nampaknya tertumpuk rapi kokoh, tetapi ternyata serba lepaslepas, setiap saat dapat dirontokkan oleh suatu sentilan dari Singgasana." Dari kalimat tersebut terdapat aspek reduplikasi utuh pada kata menara-menara yang bermakna beberapa menara, pada kata bata-bata yang bermakna benda-benda berbentuk persegi, dan pada kata lepas-lepas yang bermakna copot beberapa kali.

10. Pada bab $18 \mathrm{hlm}$. 223, terdapat kalimat yaitu "Siluet dua cikar itu seperti menerjang desa-desa, hutan-hutan, menyeberang sungai melintasi padang-padang, menyebrangi sungai lagi." Dari kalimat tersebut terdapat aspek reduplikasi utuh pada kata desa-desa yang bermakna beberapa desa, pada kata hutang-hutan yang bermakna beberapa hutan, dan pada kata padang-padang yang bermakna hamparan tanah-tanah luas.

11. Pada bab $20 \mathrm{hlm}$. 241, terdapat kalimat yaitu "Banyak muda-mudi jelata tampan-ayu, tetapi banyak pula putri-putri raden mas ayu seperti gori atau anglo saja." Dari kalimat tersebut terdapat aspek reduplikasi utuh pada kata putri-putri yang bermakna beberapa putri.

12. Pada bab 22 hlm. 250, terdapat kalimat yaitu "Dik Rara, sering kuingin, daun-daun kuning dapat kembali hijau kuncup." Dari kalimat tersebut terdapat aspek reduplikasi utuh pada kata daun-daun yang bermakna beberapa daun.

13. Pada bab $23 \mathrm{hlm}$. 257, terdapat kalimat yaitu "Tetapi pasukan pelacak yang dipimpin Penatus Jagapura sering terkacau oleh derap-derap kuda Ntir-untir dan Bolu yang arahnya justru bertolak belakang." Dari kalimat tersebut terdapat aspek reduplikasi utuh pada kata derap-derap yang bermakna suara bunyi kaki kuda yang berjalan.

14. Pada bab $25 \mathrm{hlm}$. 268, terdapat kalimat yaitu "Seperti sahabat masa kanak-kanak yang telah lama tak bersua lalu tiba-tiba muncul." Dari kalimat tersebut terdapat aspek reduplikasi utuh pada kata kanak-kanak yang bermakna periode perkembangan anak masa prasekolah dan pada kata tiba-tiba yang bermakna secara mendadak.

\section{SIMPULAN}

Hasil penelitian ini menunjukkan bahwa aspek reduplikasi yang terdapat dalam novel Rara Mendut karya Y.B. Mangunwijaya, yaitu sebagai berikut: aspek reduplikasi utuh atau murni sebanyak 287 temuan dengan persentase 53\%, aspek reduplikasi berubah bunyi sebanyak 36 temuan dengan persentase 17\%, aspek reduplikasi sebagian sebanyak 5 temuan dengan persentase $1 \%$, aspek reduplikasi berimbuhan sebanyak 131 temuan dengan persentase $29 \%$. Berdasarkan hal tersebut dari total 459 temuan aspek reduplikasi, maka dapat dinyatakan bahwa aspek reduplikasi utuh atau murni memiliki jumlah terbanyak jika dibanding dengan aspek reduplikasi lainnya. Dengan demikian dapat disimpulkan bahwa dalam novel Rara Mendut karya Y.B. Mangunwijaya, sebagian besar menggunakan aspek reduplikasi utuh atau murni.

\section{DAFTAR PUSTAKA}

Al-Ma'ruf, A. I. (2006). Dimensi sosial keagamaan dalam fiksi Indonesia modern. Solo: Smart Media.

Alwi, H., Dardjowidjojo, S., Lapoliwa, H., \& Moeliono, A. M. (2003). Tata bahasa baku bahasa Indonesia. Jakarta: Balai Pustaka.

Chaer, A. (2003). Linguistik umum. Jakarta: Rineka Cipta. 
Chaer, A. (2006). Tata bahasa praktis bahasa Indonesia. Jakarta: Rineka. Cipta

Chaer, A. (2007). Linguistik umum. Jakarta: Rineka Cipta.

Chaer, A. (2015). Morfologi bahasa Indonesia: Pendekatan proses. Jakarta: Rineka Cipta.

Moleong, L.J. (2007). Metode penelitian kualitatif. Bandung: Rosdakarya.

Ramlan. (2001). Morfologi suatu tinjauan deskriptif. Yogyakarta: Karyono.

Ridwan, R. (2018). Reduplikasi dalam buku pelajaran bahasa Indonesia kelas X Sekolah Menengah Atas (SMA). Jurnal Universitas Negeri Makassar.

Rohmadi, M., Nasucha, Y., \& Wahyudi, A. B. (2010). Morfologi: Telaah morfem dan kata. Surakarta: Yuma Pustaka.

Rohmadi, M., Nasucha, Y., \& Wahyudi, A. B. (2012). Morfologi: Telaah morfem dan kata. Surakarta: Yuma Pustaka.

Verhaar. (2004). Asas-asas linguistik umum. Yogyakarta: Gadjah Mada University Press. 